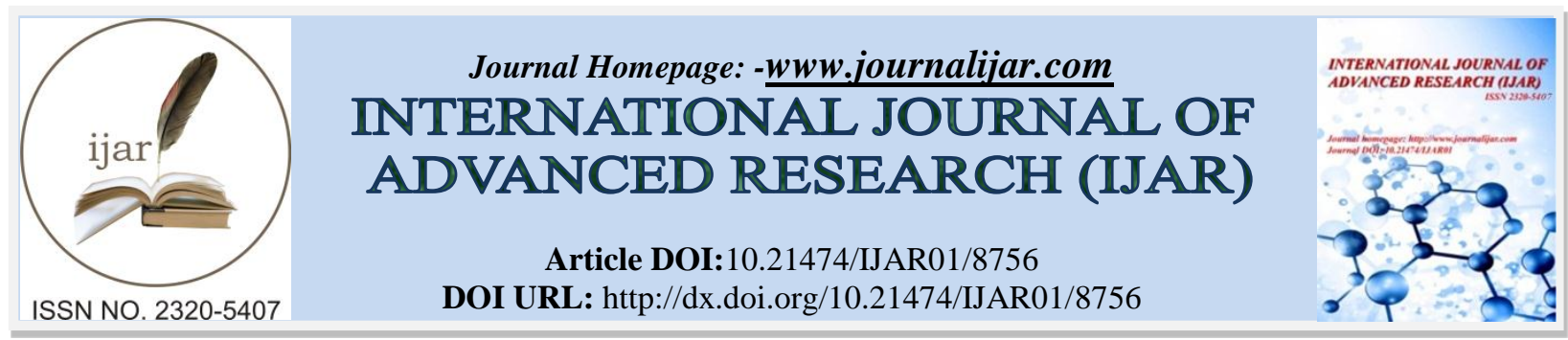

RESEARCH ARTICLE

\title{
DEVELOPMENT OF PHYSICS LEARNING INSTRUCTIONS USING RESEARCH BASED LEARNING MODEL WITH SCIENTIFIC APPROACH.
}

1. Doctoral Program, Universitas Negeri Padang.

Febri yanto $^{1}$, Festiyed ${ }^{2}$ and Mega Iswari ${ }^{3}$.

2. Faculty of Science and Maths, Universitas Negeri Padang.

3. Faculty of Science Education, Universitas Negeri Padang.

\section{Manuscript Info}

\section{Manuscript History}

Received: 20 January 2019

Final Accepted: 22 February 2019

Published: March 2019

Key words:-

research based learning, scientific approach, learning outcomes.

\begin{abstract}
Development of learning instructions is one of the abilities that must be possessed by teachers in each education unit in order to develop students' abilities in carrying out research-based learning. One of the tools that can support this goal is a learning instructions based on a research based learning model with a scientific approach. The purpose of this study is to develop physics learning instructions for senior high school by using a research based learning model with a scientific approach with valid, practical, and effective criteria. The type of research used was research and development. The development model used is the ADDIE model which consists of the analysis phase, design, development, implementation and evaluation. At the analysis stage, analysis of needs, material and analysis of students were carried out. At the design stage, preparation of research instruments and draft learning instructions in the form of lesson plans, handouts, worksheets, and assessments were conducted. At the development stage a prototype learning instructions was produced. At the test, evaluation, and revision stages, the research data were tested for validity, practicality, and effectiveness. The research shows that the senior high school physics Learning instructions using the research based learning model using the scientific approach on the wave characteristics of the material is very valid, very practical, and very effective so that it is feasible to be applied in the learning process.
\end{abstract}

Copy Right, IJAR, 2019,. All rights reserved.

\section{Introduction:-}

Educational goals can be achieved with several approaches, namely through Research Based Learning (RBL): RBL can be fully recommended for education to produce higher student motivation and improve learning outcomes and aspects of life that are better developed (Nadine 2015). It is very important to change the way s students think and uncover unknown things to improve the learning aspects of their divisions: cognitive, affective, and psychomotor. In an effort to improve academic achievement, we introduced Research Based Learning (RBL). RBL is a concept that refers to learning and teaching strategies, namely linking research and teaching (Sota, 2017: 1360). Research Based Learning is considered to increase academic achievement, learning process, and encourage students to build knowledge (Blackmore \& Fraser, 2007). This ability is very important for 21 st century education (Brew, 2010). In

Corresponding Author:-Durlav Pegu.

Address:-Research Scholar, Department of Sociology,Dibrugarh University. 
this study, the implementation of Research Based Learning is in line with the vision of developing education, while the purpose of this study is to improve student achievement. In Research Based Learning, students work individually or in groups to solve problems. Students are encouraged to find unique patterns that are different from other students. They must generalize and develop learning. Their process of finding patterns, generalizing and finding formulas become the main activities of students to increase the research data sources apart from data collected from student achievement tests.

According to Dafik (2015), RBL is a learning method that involves contextual learning, authentic learning, problem solving, cooperative learning, practical learning, and inquiry discovery approaches. The implementation of RBL aims to encourage the development of high-level thinking skills of lecturers and students. Not only students are given information and science, but are also encouraged to acquire high-level thinking skills, create or communicate. Dafik (2016) explained that Research Based Learning has advantages for students, includes increasing motivation for learning, increasing the ability to do important work, and improving problem solving skills, especially when dealing with complex problems. Wardoyo (2013: 28) states that research-based learning is learning based on a research approach (research) as a step in implementing the process. It means that the learning process that takes place is the implementation of a combination of characteristics of research actions and meaningful learning. Research-Based Learning Strategies to successfully link teaching and research, research-based learning is a multisided concept referring to various learning and teaching strategies that connect research and teaching. Exploration and learning strategies are very important in the learning process (xiaolai Liu \& qinghuai $\mathrm{Li}, 2011$ )

Good practice in research-based learning can include: the results of the study inform innovative teaching plans, research methods based on the learning process, learning to use research tools, and developing an inclusive research context (Blackmore and Fraser, 2007). What is more, RBL encourages students to be more active and thus skilled in solving complex problems, making fun learning, and increasing cooperation, interactivity, and mutual cooperation. Based on these findings, it can be affirmed that the research-based learning model is effective in achieving targets in cognitive outcomes (Alacapina 2008). Furthermore, RBL must be applied in many departments to expand research in all institutions, apply educational research, and strengthen the relationship between research and teaching (Schapper \& Mayson, 2010) In addition, it offers benefits in developing and practicing communication skills, improving students' skills in managing resources, providing experience in managing projects, assisting in the allocation of time and resources, other resources to complete tasks, and providing learning experiences involving students. Offering the benefits mentioned above, RBL empowers students to master the complex skills needed in a developing world.

\section{Research methods:-}

This type of research is Research and Development. It is to create a product that is a learning instructions on the application of dynamic fluid in technology using the Research Based Learning model. The development model used in this study was the ADDIE model. This model stands for analysis, design, development, implementation and evaluation. The concept of developing the ADDIE model is applied to build learning based on implementation; learning must be student-centered, innovative, authentic and inspirational. The ADDIE development model is a process for defining a framework with a complex situation so that this model is appropriate for developing products in education (Branch, 2009: 2). This development research is used to create a new product in learning that is to develop pphysics learning instructions for the Research Based Learning model on wave characteristics for high school. Data analysis was conducted to determine the validity and practicality of the learning instructions that had been made. The data were analyzed using descriptive statistics to obtain the mean score and percentage. Analysis of the effectiveness of learning instructions was carried out on the competencies of students' knowledge, attitudes, and skills.

\section{Research result:-}

Learning instructions Validation

Table 1:-Lesson Plan Validation Results

\begin{tabular}{|l|l|l|}
\hline Validator & Assessment $\mathbf{( \% )}$ & Category \\
\hline FE & 73,86 & Valid \\
\hline DA & 75 & Valid \\
\hline YD & 86,36 & Very Valid \\
\hline AM & 97,72 & Very Valid \\
\hline
\end{tabular}




\begin{tabular}{|l|l|l|}
\hline RD & 96,02 & Very Valid \\
\hline Average & $\mathbf{8 5 , 7 9}$ & Very Valid \\
\hline
\end{tabular}

Based on the Table 1 above, the results of the lesson plan validation are in the percentage of $73.86 \%$ to $97.72 \%$ and the mean score is of $85.79 \%$. It can be seen that almost all validation results are very valid.

Table 2:-Validation Result of the Handout

\begin{tabular}{|l|l|l|}
\hline Validator & Assessment $\mathbf{( \% )}$ & Category \\
\hline FE & 75 & Valid \\
\hline DA & 72,41 & Valid \\
\hline YD & 83,62 & Very Valid \\
\hline MI & 99,13 & Very Valid \\
\hline RD & 98,27 & Very Valid \\
\hline Average & $\mathbf{8 5 , 6 8}$ & Very Valid \\
\hline
\end{tabular}

Based on the Table 2 above, it is known that the results of handout validation are in the percentage of $72.41 \%$ up to $99.13 \%$ and the mean score is 85.68 . It can be said that almost all validation results are very valid, except the assessment given by FE and DA.

Table 3:-Results of worksheet Validation

\begin{tabular}{|l|l|l|}
\hline Validator & Assessment $\mathbf{( \% )}$ & Category \\
\hline FE & 75,00 & Valid \\
\hline DS & 77,00 & Valid \\
\hline YD & 86,00 & Very Valid \\
\hline MI & 97,00 & Very Valid \\
\hline RD & 96,00 & Very Valid \\
\hline Mean Score & $\mathbf{8 6 , 2 0}$ & Very Valid \\
\hline
\end{tabular}

Based on the results of the validation in Table 3, the results of worksheets validation are at the percentage of $75.00 \%$ to $97.00 \%$, and the mean score is $86.20 \%$. It indicates that results of worksheet validation is very valid.

\section{Practicality of learning instructions}

Practical data were taken from the results of observations on the feasibility of lesson plans and questionnaire responses of teachers and students during high school physics learning (characteristics of waves) based on the RBL learning model with the scientific approach.

\section{Results of Observation on the Implementation of RPP}

Data from the observation of the lesson plan implementation were taken from the lesson plan observation plan obtained from one observer at each meeting

Table 4:-Results of Observation on the Implementation of Lesson Plan

\begin{tabular}{|c|c|c|c|}
\hline \multirow[b]{2}{*}{ No } & \multirow[t]{2}{*}{ Meeting } & Average Observation Assessment (\%) & \multirow[t]{2}{*}{ Category } \\
\hline & & & \\
\hline 1 & First & 88,75 & Very practical \\
\hline 2 & Second & 91,25 & Very practical \\
\hline 3 & Third & 96,25 & Very practical \\
\hline \multicolumn{2}{|l|}{ Average } & 92,08 & Very practical \\
\hline
\end{tabular}

The implementation of the lesson plan for each meeting is very practical, it can seen from the preliminary aspects, core activities and closing activities during the implementation of learning takes place. The mean score of lesson plan implementation is $92.08 \%$. In general, it can be concluded that the implementation of learning using lesson plan based on the Research Based Learning model with the scientific approach on the material wave characteristics that have been developed is very practical in its use. It means that all the indicators contained in the lesson plan is implemented properly as it was planned. 
Questionnaires responsed by the students

Table 5:-Results of Analysis of Practicality Questionnaire for Teacher Responses

\begin{tabular}{|l|l|l|l|l|l|}
\hline No & $\begin{array}{l}\text { Questionnaire for } \\
\text { Teacher's Response }\end{array}$ & & $\begin{array}{l}\text { Average Observation } \\
\text { Assessment }\end{array}$ & Mean Score (\%) & Category \\
\cline { 3 - 5 } & & MI & RD & & \\
\hline 2 & Lesson Plan & 91.67 & 87.5 & 89.59 & Very practical \\
\hline 3 & Handout & 92.86 & 92.86 & 92.86 & Very practical \\
\hline 5 & Woorksheets & 95 & 95 & 95 & Very practical \\
\hline & Assessment & 100 & 87.5 & 93,75 & Very practical \\
\hline
\end{tabular}

Teacher's respond toward the learning instructions in the wave characteristics material using the Research Based Learning model with the scientific approach that has been developed is very practical. The mean score of lesson plan, handouts, worksheets, and assessments is $92.80 \%$. Practitioners assess that the instructions developed can help facilitate the teacher in conveying concepts about wave characteristics and practical use.

\section{b) Questionnaires responsed by the students}

Questionnaire is given to all students of the research class concerned to find out the practicality level of handouts and worksheets used. In summary, the results of practical assessment of students' responses after learning using handouts can be seen in Table 6.

Table 6:-Results of Practical Analysis of Questionnaire Handouts of Students' Responses

\begin{tabular}{|l|l|l|l|}
\hline No & Statement & $\begin{array}{l}\text { Value } \\
(\%)\end{array}$ & Category \\
\hline Handout & $\begin{array}{l}\text { Using the wave characteristic module makes it easy to understand the facts, } \\
\text { concepts, principles, and material procedures. }\end{array}$ & 85,00 & Very Practical \\
\hline 1 & $\begin{array}{l}\text { Using the wave characteristic module makes me quickly understand the facts, } \\
\text { concepts, principles, and material procedures. }\end{array}$ & 80,00 & Very Practical \\
\hline 3 & $\begin{array}{l}\text { Learn Physics by using wave characteristic modules makes me content with } \\
\text { knowledge of facts, concepts, principles, and material procedures. }\end{array}$ & 86,00 & Very Practical \\
\hline 4 & $\begin{array}{l}\text { Using the wave characteristic module makes me easy to understand the } \\
\text { relationship between waves and natural disasters such as tsunamis. }\end{array}$ & 89,00 & Very Practical \\
\hline 5 & Questions in the module can guide me to solve problems about waves & 84,00 & Very Practical \\
\hline 6 & The wave characteristics module is interesting to learn. & 94,00 & Very Practical \\
\hline 7 & Wave characteristic modules are interesting to read. & 95,00 & Very Practical \\
\hline 8 & Problems in wave characteristic modules can be done well. & 84,00 & Very Practical \\
\hline 9 & Problems in modular character modules are simple and interesting to learn. & 84,00 & Very Practical \\
\hline 10 & Instructions in the wave characteristic modules are easy to understand. & 85,00 & Very Practical \\
\hline Category & Very Practical \\
\hline
\end{tabular}

From the table above, it can be seen that the learning instructions used are very practical to assist the learning process. It can be seen from the questionnaire given to students; they chose very practical for every statement.

Table 7:-Results of Practicality Analysis of Worksheets Questionnaires for Students' Responses

\begin{tabular}{|l|l|l|l|}
\hline No & Statement & Score (\%) & Category \\
\hline WORKSHEETS & $\begin{array}{l}\text { By using the Lens chart character makes me easy to understand the } \\
\text { facts, concepts, principles, and material procedures. }\end{array}$ & Very Practical \\
\hline 2 & $\begin{array}{l}\text { By using worksheets characteristic waves make me quickly understand } \\
\text { material facts, concepts, principles, and procedures. }\end{array}$ & 83,00 & Very Practical \\
\hline 3 & $\begin{array}{l}\text { Physical learning using worksheets characteristic waves made me } \\
\text { satisfied with the knowledge of facts, concepts, principles, and material } \\
\text { procedures. }\end{array}$ & 86,00 & Very Practical \\
\hline 4 & The questions in the worksheets characteristic of the wave led me to & 89,00 & Very Practical \\
\hline
\end{tabular}




\begin{tabular}{|l|l|l|l|}
\hline & solve the wave problem and its affinity with events caused by wave & & \\
\hline 5 & Worksheets about characteristic of waves are easy to learn. & 85,00 & Very Practical \\
\hline 6 & Worksheets about characteristic of wave are easy to read. & 87,00 & Very Practical \\
\hline 7 & Problems in worksheets characteristic of the wave can be done well. & 86,00 & Very Practical \\
\hline 8 & Problems in worksheets are simple and attractive wave characteristics. & 87,00 & Very Practical \\
\hline 9 & Steps in the worksheets characteristic feature are easy to follow. & 83,00 & Very Practical \\
\hline 10 & $\begin{array}{l}\text { Instructions in the worksheet of wave characteristics are easy to } \\
\text { understand. }\end{array}$ & Very Practical \\
\hline
\end{tabular}

Based on students' response to the worksheets developed, it can be said that it is very practical. Based on the score obtained from lesson plan, observations, questionnaires (teacher and students), it can be seen that the learning instructions developed is very practical.

\section{Effectiveness of Using Learning instructions}

Effectiveness of the use of learning instructions data were taken from the results of the knowledge, attitudes and skills of students. The results of the effectiveness of the appraisal can be seen in the following description:

\section{Results of the Knowledge Competency Assessment}

Data of student achievement on the knowledge dimension were obtained from the results of tests and assessments in writing at each meeting. The results of the first meeting were the results of the pretest regarding wave characteristics; the second meeting was the score of the worksheets answer, while the third meeting was the final test result of learning wave characteristics. In summary, the results can be seen in Table 8

Table 8:-Results of Student Knowledge Competency Assessment

\begin{tabular}{|l|l|l|l|l|l|}
\hline $\begin{array}{l}\text { Meeting } \\
\text { To- }\end{array}$ & Mean Score & Predicate & $\begin{array}{l}\text { Students Who } \\
\text { Pass }\end{array}$ & $\begin{array}{l}\text { Students who not } \\
\text { pass }\end{array}$ & Completeness (\%) \\
\hline I & 82,60 & B & 22 & 8 & 73,3 \\
\hline II & 84,00 & B & 24 & 6 & 80,0 \\
\hline III & 88,40 & B & 27 & 3 & 90,0 \\
\hline Average & 85,00 & B & 24 & 6 & 81,1 \\
\hline
\end{tabular}

The mean score of student achievement on the knowledge dimension can be seen that 8 students scores in the first meeting, 6 students in the second meeting and 3 students in the third meeting are under the Minimum Proficiency Criteria $(<80)$. The mean score for the three meetings is $85 \%$, while the percentage of learning completeness reaches $81.1 \%$. From Table 8 , it can also be seen that students' knowledge competencies have increased at each meeting.

From the results of the knowledge competency data analysis for each meeting conducted, it can be seen that the mean score of students is only around $85 \%$. This value is greater than the classic Minimum Completion Criteria (KKM) set by the school which is 80 . Thus, if we are guided by the KKM School, the value of classical students' knowledge can be said to be complete. If you see the completeness of students individually, then there are more than $70 \%$ of the number of students in the class who have achieved KKM or completed. This is because students have been able to follow wave characteristics learning well. The selection of the Research Based Learning model is quite challenging students because learning starts from presenting interesting natural phenomena and close to the lives of students. The division of study groups is arranged heterogeneously. The leader of each group was chosen from students who were ranked in the class to organize and instruct their friends who had lower levels of learning ability. The time allocation for each learning activity is also sufficient and in accordance with the lesson plan.

In the third meeting, it was seen that student achievement had improved compared to previous meetings. The mean score of completeness reaches $88.4 \%$ which is greater than classical completeness, $80.0 \%$. Thus, it can be said that the development of learning instructions for the wave characteristic material based on the Research Based Learning model with the scientific approach can increase students' knowledge of the material characteristics of waves 


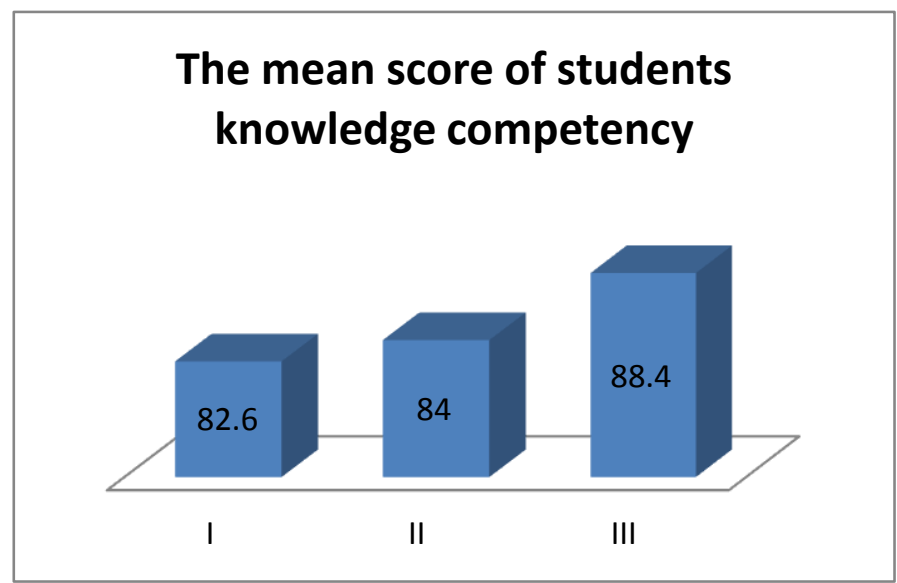

Figure 1:-The average value of student knowledge competencies

Based on Figure 1, it can be seen that the mean score of students' knowledge increases from each meeting, from $82.6 \%$, up to $88.4 \%$. It can be seen that using the Research Based Learning model with the scientific approach to teach wave characteristics can increase the effectiveness of students' knowledge competencies.

\section{Results of Attitude Competency Assessment}

The attitude competency assessment in this study was carried out by observation. Assessment of student attitudes was conducted every meeting by the observer through an observation sheet on attitude assessment. This assessment was conducted to see how far the students' desires and good attitudes in responding to the learning done, can be briefly seen in Table

Table 9:-Recapitulation of Results of Student Attitude Competency Assessment

\begin{tabular}{|l|l|l|l|l|l|}
\hline \multirow{2}{*}{ Observation Aspect } & \multicolumn{2}{l}{ Score/Meeting (\%) } & Mean Score & Category \\
\cline { 2 - 5 } & $\mathbf{1}$ & $\mathbf{2}$ & $\mathbf{3}$ & & \\
\hline Spiritual attitude & 75,8 & 77,5 & 80 & 77,8 & Good \\
\hline Mujahadah & 77,5 & 95 & 91,7 & 88,1 & Very Good \\
\hline Pray & 80,0 & 88,3 & 93,3 & 87,5 & Very Good \\
\hline Thank you & 80,0 & 81,7 & 90 & 83,9 & Very Good \\
\hline Patience & 70 & 79,2 & 85 & 78,1 & Good \\
\hline Social Attitude & 70 & 83,3 & 92,5 & 86,1 & Very Good \\
\hline Critical & 82,5 & 80,8 & 90 & 82,2 & Good \\
\hline Creative & 75,8 & 70,2 & 83,3 & 76,1 & Good \\
\hline Logical & 70,8 & 74,2 & 90,3 & Very Good \\
\hline Analytics & 87,5 & 88,3 & 95 & 90,3 & \\
\hline Curiousity &
\end{tabular}

Table above shows that overall the attitudes of students are very good category, 83.34\%. From each meeting, students' attitudes increased. It shows that by using wave characteristics learning instructions using the Research based learning model with the scientific approach, student attitudes can be better in the learning process. It can be said that the development of instructions can improve student achievements in the attitude and even more if the development of this learning instructions is more in-depth and better application.

\section{Skills Competency Assessment Results}

Data on the effectiveness of the use of learning instructions were also obtained from observations of students' skills in research-based learning based on modern learning with the scientific approach. The results of the analysis can be seen in Table 10 
Table 10:-Results of Student Skills Competency Assessment

\begin{tabular}{|l|l|l|}
\hline Observation Aspect & Value & Predicate \\
\hline Positioning tools & 79,2 & B- \\
\hline Arrange Tools & 85,8 & B+ \\
\hline Determine the waveform & 82,5 & B \\
\hline Looking for relationships & 89,2 & B+ \\
\hline Make a graph & 85 & B+ \\
\hline Mean Score & $\mathbf{8 4 , 3 4}$ & B \\
\hline
\end{tabular}

Based on Table 10, the mean score of students` skill is $84.34 \%$, B. It means that learning instructions in the material wave characteristics using the Research Based Learning model with the scientific approach can help students carry out experiments as part of scientific learning contained in the curriculum.

Figure 3:-Score of student skill

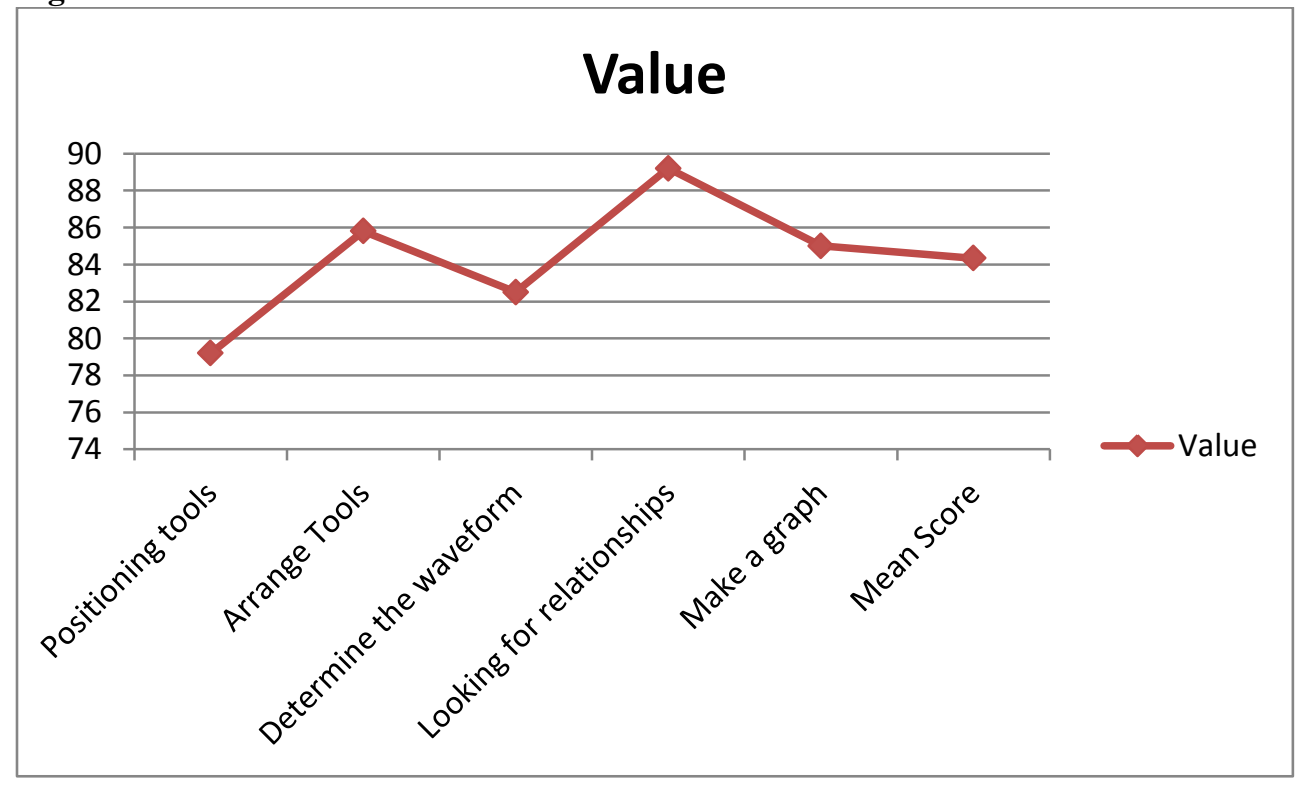

Based on Figure 3, it can be seen that the mean score of students skill is $84.34 \%$ and it is in the B predicate. It means that using the Research Based Learning model using the scientific approach to wave characteristics can improve students' competency skills so that the devices developed can be effective.

\section{Conclusion:-}

Based on the development and trials that have been conducted on learning instructions based on the Research Based Learning model with the scientific approach on the material characteristics of waves, the following conclusions are obtained.

1. The validity of learning instructions for wave characteristics based on the Research Based Learning model with the scientific approach which was assessed by 5 validators shows that the learning instructions based on the Research Based Learning model with the scientific approach to the wave characteristic material is very valid.

2. Practicality assessed from observations of the implementation of lesson plans by observers and the results of teacher response questionnaire analysis and student response questionnaires showing learning instructions based on the Research Based Learning model with the scientific approach to the material characteristics of waves are very practical in their use.

3. Effectiveness assessed from the analysis of learning outcomes in attitudinal, knowledge and skills competencies and questionnaire analysis of teacher and student responses shows that learning instructions based on the Research Based Learning model with the scientific approach to the material wave characteristics are in effective criteria. 


\section{References:-}

1. Blackmore, P., \& Fraser, M. (2007). Research Based Learning Strategies for Successfully Linking Teaching and Research. Journal of Education, 13(2), 1-13.

2. Branch, Robert Maribe.(2009). Instructional design : the ADDIE Approach. New York : springer

3. Brew, A. (2010). Imperatives and Challenges in Integrating Teaching and Research. Higher Education Research \& Development, 29(2), 139-150.

4. Dafik. (2015). Graph Theory, Applications and The Growth of High-Level Thinking Skills. CGANT Research Group Universitas Jember.

5. Dafik. (2016). Developing and Research Based Curriculum for Higher Education. Jember: Universitas Jember.

6. Marks, Nadine \& Lambert, James. (1997). Transitions to Caregiving, Gender, and Psychological WellBeing:Prospective Evidence from the National Survey of Families and Households. Madison, University Wisconsin.

7. Sota,C.,\& Karl, P.(2017).The Effectiveness of Research Based Learning among Master degree Student for Health Promotion and Preventable Disease, Faculty of Public Health, Khon Kaen University, Thailand. Procedia-Social and Behavioral Sciences, 237, 1359-1365.

8. Schapper, J., \& Mayson, S. E. (2010). Research-led Teaching: Moving from a Fractured Engagement to a Marriage of Convenience. Higher Education Research \& Development, 29, 641-651.

9. Wardoyo, Sigit Mangun. (2013). Research Based Learning. Jakarta: Akademia Permata.

10. Xiaolai Liu, Qinghuai Li (2011) combabination of the research-Based Learning Method with the Modren Physics Experiment Course Teaching, Vol 4,No.1;February 2011 